Poezja (bezkrytycznego) świadectwa (Anna Skoczek: Poezja świadectwa i sprzeciwu. Stan wojenny w twórczości wybranych polskich poetów, Kraków 2004)

Agnieszka Dębska 


\section{Poezja (bezkrytycznego) świadectwa}

Pomimo istnicjących już rozpoznań tematu poezji stanu wojennego (w postaci ksiązek Danuty Dąbrowskiej i Dobrochny Dabert) nowa publikacja z tego zakresu wydaje się pozycją interesującą i wartą bliższej uwagi'. Zwlaszcza, że przynosi ona wiele cennych spostrzeżeń, systematyzując jednocześnie dotychczasowy stan badań.

Pracę Anny Skoczek cechuje duże uporządkowanie, pozwalające na obejrzenie zebranego, bogatego materiałı źródłowego z kilku perspektyw. Wychodząc od przypomnienia tła historycznego (rozdz. I), poprzez opis poezji okolicznościowej - postrzeganej zarówno jako przejaw „świadectwa”, jak i element dialogu z tradycją - dochodzi autorka do przedstawienia poetyki wybranych twórców, traktując ich jako odrębne pokolenie naznaczone doświadczeniem stanu wojennego, odróżniające się wyraźnie od nowofalowych poprzedników i „Brulionowych” następców.

Oba bieguny poezji stanu wojennego: „okolicznościowy” i „wysoki” zaprezentowane zostały w sposób sprawny i interesujący; jedyne, co budzić może pewien niedosyt, to whaśnie ich usytuowanie obok siebie, bez możliwości konfrontacji - niezauważonej przez badaczkę, choć przecież istniejącej, pomimo zasadniczo odmiennych kategorii wykorzystanych do badań obu obszarów.

Opisanie wierszowanej twórczości powstającej po 13 grudnia jako poezji okolicznościowej funkcjonującej w obiegu folklorystycznym (rozdz. II), pozwala na wyeksponowanie roli „świadectwa”, przy zachowaniu pamięci o znaczeniu, jakie temu terminowi nadał Stanisław Barańczak w książce Poeta pamięta. Antologia poezji śmiadectu'a i sprzeciu'u (zresztą Anna Skoczek nawiązuje tytulem swojej pracy do tej publikacji). Owo świadectwo realizowane jest poprzez trzy możliwości - określone przez autorkę jako „spectra”: historyczne, dokumentalistyczne i socjologiczne (rozdz. III). Pierwsze z nich obejmuje utwory odwohujące się do najważniejszych wydarzeń stanu wojennego, drugie pokazıje wiersze dokumentujące życie w warunkach internowania (tu na uwage zasługuje zwlaszcza duża staranność w przypisaniu poszczególnych utworów do konkretnych miejsc odosobnienia), trzecie wreszcie - gromadzi teksty komentujące odczucia i zachowania spoleczeństwa poddanego rygorom stanu wojennego.

Kolejnym narzędziem, które okazuje się niezwykle przydatne do porządkowania pogrudıiowej poezji, jest klucz odniesień do tradycji, odniesień rzeczywiście bogatych i róznorodnych (rozdz. IV). Autorka szczególnie tutaj podkreśla - co w pełni zrozuniale — rolę tradycji romantyczncj, zauważając wszakże bardzo trafnie jej „rekwizytowe” użycie - na przykład gdy pisze o modyfikacji motywu tyrtejskiego, funkcjonującego raczej jako „odwołanie do tradycji walki niż wezwanie bezpośrednie” (s. 65). Osobny, bardzo obszerny podrozdział poświęcony został „kontrafakturze”, czyli typowemu dla każdej poezji

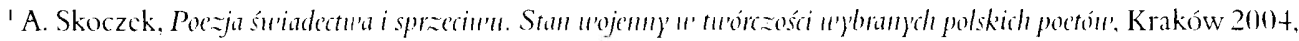
Wydawnictwo SMS, s. 239. 
okolicznościowej (i opisanemu już wcześniej w odniesieniu do literatury stanu wojennego przez Dobrochnę Dabert) zjawisku tworzenia nowego tekstu do znanej melodii. Anna Skoczek bardzo skrupulatnie przedstawia wszystkie możliwe typy utworów slużących za pierwowzory, dając tym samym obraz niesłychanej pomysłowości anonimowych twórców. Być może jednak do wyborów dokonywanych przez autorów zaktualizowanych Rot, Warszal'ianek itd. należy podejść z większą ostrożnością, wydaje się bowiem, że czasem za naśladowaniem tej czy innej melodii popularnej pieśni stoi jedynie jej rozpoznawalność (zaświadczona już wcześniej okolicznościowymi przeróbkami powstającymi w innych warunkach historycznych), a nie świadoma decyzja o utożsamieniu z wartościami, do których odwolywal się pierwowzór. Widać to szczególnie w przypadku nawiązani do polskich pieśni rewolucyjnych, trudno bowiem zgodzić się z twierdzeniem, że „Nadawcy tekstów okolicznościowej poezji stanu wojennego wykazujją świadomość dziewiętnastowiecznej demokracji, myśli PPS, ale i świadoność socjalistyczną PZPR" (s. 71). Przypuszczać można, że owe nawiązania są bardziej sprawą poetyki niz świadomości.

Także przyczyny popularności tradycji kolędowo-modlitewnej zostały przez autorkę nieco przecenione. $Z$ pewnością wykorzystanie niektórych jej elementów znacznie lepiej (i prościej) thumaczy się w kategoriach zabiegów typowych dla poetyki twórczości okolicznościowej (aktualizacja tekstu kolędy, szopka satyryczna) niz jako „dalekie echa zachowań mitycznych czlowieka archaicznego" (s. 88).

Osobny rozdział (V) poświęcony zostal językowi, jednak wydaje się, że bardziej niż o język samej poezji chodzi tu o mowę jako .świat przedstawiony", głównym przedmiotem opisu jest bowiem „polemika z językiem propagandy politycznej” (s. 106). Takie ujęcie jest z jednej strony dość znamiemne - pokazuje, że myślenie o języku zawarte w twórczości „pogrudniowej” było wciąż pod silnym wpływem kierunku wypracowanego przez poezję Nowej Fali, ale z drugiej - nie pozwala ono na nadmierną oryginalność. Autorka poshuguje się tymi samymi kategoriami, których używała w swojej książce Dobrochna Dabert, pisząc o walce z nowomową, zwrocie w stronę języka potocznego, nobilitowaniu gwary, wykorzystanin inwektywy itd. Nowe elementy to dostrzeżenie roli dowcipu i słownej zabawy oraz ciekawe (choć przydałaby się tı większa niż jeden tomik skala przebadanego materiału) wyniki badań frekwencyjnych - pokazujące zespół preferowanych wartości wyrażony w języku analizowanych utworów.

Kolejne rozdziały poświęcone zostały poezji „wysokiej”, czyli obecności tematyki stanu wojennego w twórczości wybranych poetów. Dokonując przeglądı pogrudniowych tomików (rozdz. VI), autorka zwraca uwagę na postawę narratora (podrozdział Kronikarski zapis), pesymistyczną wizję historii (Fatalizm historii) oraz na wykorzystanie elementów tradycji romantycznej (Wzorzec romantyczno-martyrologiczny' - tu na uwagę zasługuje dostrzezenie połowiczności współczesnego mesjanizmu, w którym brak miejsca na idę̨ pocieszenia). Następnie Anna Skoczek przedstawia trzy przyblizenia (rozdz. VII), zajmując się kolejno twórczością Tomasza Jastruna, Jan Polkowskiego i Bronisława Maja. Każdy z trzech szkiców zawiera trafną i wieloaspektową charakterystykę poetyki omawianego autora. Jastrun 
jest pokazany przede wszystkim jako poeta metafory budowanej „z konkretu rzeczywistości stanu wojennego" (s. 168). U Polkowskiego ,konkret ewolunje w stronę epifanii” (s. 170). Niepotrzebne wydaje się natomiast radykalne rozdziclenie nurtu epifanicznego i katastroficznego w poezji autora Elegii z tymouskidh gór (s. 176). Epifania dokonuje się tu bowiem raczej przy stałej obecności świadomości katastrofy i - niejako - pomimo niej. Związek poezji Bronisława Maja z tematyką stanu wojennego jawi się jako najmniej oczywisty z calej trójki, co zresztą autorka samı przyznaje, pisząc, iż konkret stanu wojennego jest w tej poezji „ledwo dostrzegalny, marginalny” (s. 179). Uwaga czytelnika skupiona zostaje zatem na „refleksyjno-intelektualnym” charakterze tej twórczości, opisywanej w kategoriach poezji metafizycznej. Jeśli problem stanı wojennego siç tu w ogóle pojawia, to jedynie jako element ogólnej refleksji nad czasem i historią. (Dzieje się tak zapewne dlatego, że dla tego krakowskiego poety stan wojenny jest przede wszystkim zagadnieniem moralnym, a nie - przedmiotem opisı).

O ile więc wypada się zgodzić z zaproponowanymi przez badaczkę rozpoznaniami szczegółowymi, o tyle wątpliwości budzi sprawa bardziej zasadnicza, a mianowicie próba pokazania trzech wymienionych poetów jako przedstawicieli „pokolenia stanu wojennego”, pokolenia, do którego autorka zalicza także - oprócz wymienionych - między innymi Antoniego Pawlaka, Lothara Ierbsta, Leszka Szarugę oraz anonimowych twórców, „którzy włączyli się do krytyki zaistniałej rzeczywistości” (s. 25). Wprowadzenie kategorii pokoleniowej, niefunkcjonującej w dotychczasowych badaniach, wydaje się pozbawione uzasadnienia. Podstawową cechą poezji stanu wojennego jest bowiem to, ze w jej tworzeniu uczestniczyli autorzy przynależący do najrozmaitszych generacji, i że - zadziwiająca nieraz — wspólnota nie tylko rozpoznań sytuacji, ale i środków użytych do jej wyartykułowania, osiągana byla niezależnie od pokoleniowych podziatów. Trudno nazwać pokoleniowym doświadczenie, do którego odnosili się w tym samym czasie ponad siedendziesięcioletni Jerzy Zagórski i dwudziestolatek Piotr Szafarz.

Stan wojemny wręcz wyróżnia się tym, że się nie stal — choć pewnie móglby, w innych warunkach - przeżyciem pokoleniowym (chyba że dla tak zwanego .pokolenia Teleranka" - ale to zupełnie inna historia...) i znacznie bardziej pasuje do niego, w plaszczyźnie doświadczeń literackich, dostrzeżona przez autorkę, acz niewykorzystama kategoria „wyzwania" (s. 195).

Także jeśli chodzi o twórców uznanych za najbardziej typowych przedstawicicli „pokolenia 81" - Jastruna, Polkowskiego i Maja — trudno się zgodzić z przekonaniem, ze w ich przypadku „stan wojenny zaważył na sztuce poetyckiego wyrazu” (s. 162), wszyscy trzej wkroczyli bowiem w lata osiemdziesiąte juz jako w pełni uksztaltowane osobowości poetyckie. Tłumaczenie obecnego w ich twórczości katastrofizmu traumą stanu wojennego jest zawężeniem perspektywy, tonacja ta była bowiem niezwykle mocno obecna w poezji końca lat siedemdziesiątych (zwhaszcza ı Polkowskiego czy Szarugi), a w warunkach stanu wojennego doszlo jedynie do jej ponownego wzmocnienia. Nim "traumatyzm, bezradność, poczucie krzywdy" (s. 210) zagościly w wierszach z okresu stanu wojennego, byly 
istotnym składnikicm poetyki Nowych Roczników - pozbawionych nadziei po klęsce nowofalowego „zadufania”, należały do - opisanej przez. Edwarda Balcerzana — „psychosfery" pokolenia 76.

Tę nieprzydatność generacyjnych określeń widać szczególnie, gdy autorka próbuje pokazać specyfikę „pokolenia 81" na tle twórczości „poprzedników” i „następców”, czyli przedstawicieli Nowej Fali i poetów „Brulionu” (rozdz. VIII). O ile wyrazista - wielokrotnie deklarowana - odrębność poetów „Brulionu” nie budzi wątpliwości, to przegląd poetyckich postaw pokolenia 68 pozwala dostrzec, że pomiędzy aksjologicznym nastawieniem Krynickiego czy uniwersalizmem Zagajewskiego a stosunkiem do ówczesnej rzeczywistości wyrażonym w twórczości Maja czy Polkowskiego nie ma wcale tak zasadniczych różnic. Istotnym kryterium podzialu bylaby obecność lub brak ironii i dystansu (s. 210), lecz cechowala ona nie tylko przedstawicieli Nowej Fali (choć i tu - nie wszystkich próżno go szukać u Karaska czy Herbsta), ale i zarówno poetów starszych (Międzyrzecki, Woroszylski), jak i młodszych (Budrewicz, Mitzner), jej brak zaś byl w pierwszym rzędzie domeną twórczości amatorskiej.

W samym zakończeniu ksiązki pojawia się jeszcze jedno, dość istotne dookreślenie miejsca omawianej poezji. Autorka z jednej strony widzi w niej finalny element romantycznego paradygmatu (s. 220), z drugiej zaś dostrzega możliwy ciąg dalszy - wskazıjąc na wspólczesne przejawy poezji okolicznościowej, które - jej zdaniem - nawiązują do tradycji twórczości stanu wojennego. To ostatnie stwierdzenie wydaje się co prawda mniej oczywiste, ale samo umieszczenie pogrudniowej poezji w pewnym ciągu tradycji, posiadającej możliwe kontynuacje, jest propozycją wartą zauważenia.

Podobnie zresztą jak i cała książka krakowskiej badaczki, która jest pozycją interesującą i wartościową, pomimo drobnych potknięć. Gwoli sprostowaniu należy bowiem zauważyć, że opisany jako wiersz Karaska Szkic do scen z Grottgera (s. 149) jest w rzeczywistości utworem Jacka Bièrezina (mylenie obu autorów, którzy mieli nieszczęście podobnie zatytułować swoje teksty, stało się już swego rodzaju tradycja); z kolei kontekstem dla analizowanych wierszy Polkowskiego Finis Poloniae i Którzy nie widzieli nie może być stan wojenny - bo są to utwory wcześniejsze (ten pierwszy nawiązuje prawdopodobnie do VIII Zjazdı Partii). Z drugiej strony pewien niepokój budzi swoiste absolutyzowanie zawartego w poezji świadectwa. Autorka uważa bowiem, że „w poźółkłych tomikach wierszy odbitych na powielaczu zamknięta jest wiedza o przeżyciach narodu. Sięgając po nie w nowej sytuacji politycznej, nie szuka się kunsztu poetyckiego lecz prawdy o nieistniejącej juz rzeczywistości i świadectwa minionego czasu" (s. 144).

Taka postawa skutkıje dość bezkrytycznym uznawaniem opisanych w poezji zdarzeń za prawdę historyczną, co bywa czasem zawodne (na przykład w przypadku wiersza mówiącego o śmierci Grzegorza Przemyka - s. 46), zwlaszcza gdy mamy do czynienia z oczywistą hiperbolizacją, od której analizowana twórczość bynajmniej nie stronila. Nadmierną rolę przypisuje także badaczka aluzji. Na przykład zdanie „Zamknęli nam Lecha” nie jest bynajmniej - jak twierdzi autorka - aluzją do internowania Lecha Wałęsy (s. 54), także 
dlatego, że poezji stanu wojennego nie było stać na subtelność aluzji. Nie zawsze też udaje się oddzielić język opisu od przedmiotu analizy - stąd duże emocjonalne nacechowanie zwłaszcza początkowych rozdziałów książki, które na szczęście później zanika.

Wszystko to jednak nie zmienia faktu, ze wiedza na temat, dotąd nieco lekceważonej, poezji stanu wojennego została właśnie w znaczący sposób wzbogacona.

Agnicsaka Dęloska 